Rev. Int. Contam. Ambie. 36 (3) 607-622, 2020

https://doi.org/10.20937/RICA.53381

\title{
ELECTROSYNTHESIS OF SODIUM AND POTASSIUM FERRATE FOR THE TREATMENT OF INDIGO BLUE AQUEOUS SOLUTIONS AND DENIM WASTEWATER
}

Electrosíntesis de ferrato de sodio y potasio para el tratamiento de solución acuosa de azul índigo y agua residual de la industria de la mezclilla

\author{
Monserrat CASTAÑEDA JUÁREZ ${ }^{1}$, Verónica MARTÍNEZ MIRANDA ${ }^{1}$, \\ Perla Tatiana ALMAZÁN SÁNCHEZ ${ }^{2}$, Ivonne LINARES HERNÁNDEZ ${ }^{1 *}$ \\ and Guadalupe VÁZQUEZ MEJÍA ${ }^{1}$
}

${ }^{1}$ Instituto Interamericano de Tecnología y Ciencias del Agua. Universidad Autónoma del Estado de México. Carretera Toluca-Ixtlahuaca, km 14.5, Unidad San Cayetano, C.P 50200, Toluca, Estado de México, México ${ }^{2}$ CONACyT-Instituto Nacional de Investigaciones Nucleares. Departamento de Química. Carretera MéxicoToluca s/n, La Marquesa, C.P. 52750 Ocoyoacac, Estado de México, México

*Author for correspondence: ilinaresh@uaemex.mx

(Received: August 2018; accepted: November 2019)

Key words: wastewater treatment, coagulation-flocculation, oxidation, textile effluent, biodegradability index

\begin{abstract}
Synthetic dyes are widely used in the textile industry. It is estimated that about 2-50\% of these dyes are lost during the dying process and released in the effluents. These compounds are highly colored and can cause severe contamination of water sources. In this study, ferrate has been employed for the treatment of indigo blue aqueous solutions and denim wastewater. The electrosynthesis of ferrate was carried out using a $2^{4}$ factorial design and the optimal conditions were found: current density of $100 \mathrm{~mA} / \mathrm{cm}^{2}$, room temperature, kind and concentration of electrolyte, $\mathrm{NaOH} 20 \mathrm{M}$. Under these conditions, $6.89 \mathrm{~g} / \mathrm{L}(41.54 \mathrm{mM})$ of ferrate was produced. The successful synthesis of ferrate was confirmed using infrared spectroscopy, ultraviolet spectroscopy, and cyclic voltammetry. The electrosynthesized sodium ferrate $\left(\mathrm{Na}_{2} \mathrm{FeO}_{4}\right)$ and potassium ferrate $\left(\mathrm{K}_{2} \mathrm{FeO}_{4}\right)$ were evaluated in a jar test. The maximum dye removal percentage (>77\%) was achieved using $\mathrm{Na}_{2} \mathrm{FeO}_{4}$ at a dose of $300 \mathrm{mg} / \mathrm{L}$. In denim wastewater, the best color removal efficiency was $92.51 \%$ using $200 \mathrm{mg} / \mathrm{L}$ of $\mathrm{K}_{2} \mathrm{FeO}_{4}$ at $30 \mathrm{~min}$. The increased biodegradability index $(0.98)$ after treatment by $\mathrm{K}_{2} \mathrm{FeO}_{4}$ confirmed that the biorefractory compounds were oxidized/removed.
\end{abstract}

Palabras clave: tratamiento de aguas residuales, coagulación-floculación, efluente textil, índice de biodegradabilidad

\section{RESUMEN}

Los colorantes sintéticos son ampliamente utilizados en la industria textil, se estima que aproximadamente del 2 al $50 \%$ de estos son perdidos durante el proceso de teñido y conducidos hacia los efluentes en donde han ocasionado una contaminación severa. Por lo tanto, en este estudio, se utilizó ferrato para tratar soluciones acuosas de azul índigo y agua residual textil. La electrosíntesis de ferrato se realizó mediante 
un diseño factorial $2^{4}$ para obtener las mejores condiciones de operación a una densidad de corriente de $100 \mathrm{~mA} / \mathrm{cm}^{2}$, temperatura ambiente, tipo y concentración del electrolito, $\mathrm{NaOH} 20$ M. Bajo estas condiciones se obtuvieron $6.89 \mathrm{~g} / \mathrm{L}$ (41.54 $\mathrm{mM}$ ) de ferrato. Se utilizó espectroscopia de infrarrojo, espectroscopía UV-Vis y voltamperometría cíclica para corroborar la presencia del mismo y se evaluó mediante la prueba de jarras. El máximo porcentaje de remoción (> 77 \%) se obtuvo utilizando $300 \mathrm{mg} / \mathrm{L}$ de ferrato de sodio. En el agua residual textil, la mejor eficiencia de remoción de color fue de $92.51 \%$ con $200 \mathrm{mg} / \mathrm{L}$ de ferrato de potasio en 30 min. Finalmente, se observó un incremento en el índice de biodegradabilidad (0.98) después del tratamiento con ferrato de potasio, el cual confirmó que los compuestos biorefractarios fueron oxidados/removidos.

\section{INTRODUCTION}

The exact amount of synthetic organic dyes produced in the world is unknown, but more than 1 million tons per year (Ali 2010) are used in the textile, leather-tanning, paper production, food technology, photoelectrochemical cell, and hair coloring industries.

Azo, anthraquinone, sulfur, indigoid, triphenylmethyl (trityl), and phthalocyanine derivatives represent the most commonly used dyes on the industrial scale (Forgacs et al. 2004). Due to their large-scale production and extensive application, these synthetic dyes can cause considerable environmental pollution (Nawaz and Ahsan 2014) and serious health risks (Forgacs et al. 2004, de Jager et al. 2014).

Indigo blue dye is the main raw material used in the process of denim dyeing. This dye contains a ketonic group $(\mathrm{C}=\mathrm{O})$, and is water-insoluble. Wastewater containing indigo blue dye is characterized by a dark blue color due to the presence of the residual dye that was not fixed to the fiber during the dyeing process (Albuquerque et al. 2013) and the presence of unreactive hydrolyzed dye in the dyebath (Pearce et al. 2003). Dye loss in the effluent can range from $2 \%$ to $50 \%$ depending on the dye type (Pearce et al. 2003, Forgacs et al. 2004, Martínez-Huitle and Brillas 2009, Punzi et al. 2012, Khandegar and Saroha 2013). The poor biodegradability of denim wastewater is caused by the presence of color, nutrients (nitrogen and phosphorus), inorganic salts, refractory organics (Karthikey et al. 2011, de Jager et al. 2014), total suspended solids (TSS), chemical oxygen demand (COD), variable $\mathrm{pH}$ (2 to 12), and toxic compounds such as surfactants, heavy metals, and chlorinated organic compounds (Raghu et al. 2009, Khandegar and Saroha 2013, Blanco et al. 2014, Manenti et al. 2014). It is estimated that $280000 \mathrm{t}$ of textile dyes are discharged in industrial textile effluent every year worldwide (Ali 2010).
Various physical, chemical, biological, enzymatic, and electrochemical technologies have been widely used to treat textile effluents (Martínez-Huitle and Brillas 2009). Among these, ferrate oxidation is considered to be an environmental friendly technique for pollution control and an efficient tool for dye degradation. The oxidizing power of ferrate is higher than those of common oxidants such as permanganate, ozone, and hypochlorite ( $\mathrm{Li}$ et al. 2005, Eng et al. 2006, Han et al. 2018, Rai et al. 2018).

During the oxidation of dyes, ferrate is reduced to $\mathrm{Fe}(\mathrm{III})$; therefore, ferrate exhibits coagulating properties as a consequence of ferric hydroxide $\left(\mathrm{Fe}(\mathrm{OH})_{3}\right)$ formation. This coagulation can greatly enhance the aggregation and settling processes (Eng et al. 2006, Alsheyab et al. 2009, Rai et al. 2018, Shin et al. 2018), and is considered beneficial for water treatment processes. A variety of industrial wastewater pollutants have been treated by ferrates, including inorganic contaminants, nitrogen-containing pollutants, organosulfur compounds, nutrients, some metals, emerging pollutants, and microorganisms (Eng et al. 2006, Nikolić-Bujanović et al. 2011, Villanueva-Rodríguez et al. 2012, Han et al. 2018).

There are two basic methods for ferrate production: chemical and electrochemical methods. The chemical methods are based on combining iron compounds, such as iron (III) nitrate and iron oxide, with an oxidizing material in an alkaline environment. In contrast, electrochemical methods usually involve the use of a sacrificial iron anode in an electrolysis cell containing a strongly alkaline solution such as $\mathrm{NaOH}$ or $\mathrm{KOH}$. A direct current is applied to oxidize the $\mathrm{Fe}^{0}$ to $\mathrm{Fe}$ (VI) (De Koninck and Bélanger 2003, Alsheyab et al. 2009, Mácová et al. 2009, VillanuevaRodríguez et al. 2012).

On this basis, the use of electrochemically synthesized sodium and potassium ferrate was proposed for the treatment of indigo blue aqueous solutions and denim wastewater. The electrochemical synthesis was 
carried out using a batch cell and a Fe-BDD (boron doped diamond) anode/cathode. The synthesis of ferrate ions by electrochemical means depends strongly on the applied current density, electrode material, active area, temperature, reactor design, iron concentration, and electrolyte used. These parameters were evaluated using a $2^{4}$ factorial design. It is important to note that while the great majority of the studies using sodium or potassium ferrate have been carried out only in an aqueous solution, in this work, the ferrate compounds were applied to real wastewater, giving this work additional significance.

\section{MATERIAL AND METHODS}

\section{Electrochemical synthesis of ferrate}

The electrosynthesis was accomplished according to the $2^{4}$ factorial shown in table I. The variables of temperature, current density, and the type and concentration of the electrolyte were analyzed and contrasted using the Yates algorithm and the " $F$ " test to determine which had the main effect on the electrosynthesis of ferrate. The experiments were carried out in an electrochemical batch cell using iron as the anode and BDD as the cathode; the anodic surface area was $12 \mathrm{~cm}^{2} .30 \mathrm{~mL}$ of the electrolyte was placed in the electrosynthesis reactor, and the current intensity was controlled using a power supply and a digital multimeter. The concentration of ferrate was determined by measuring the absorbance at $505 \mathrm{~nm}$ using a Varian Cary E1 spectrophotometer, and applying a molar absorption coefficient of 1150 $1 / \mathrm{M} / \mathrm{cm}$ (Lee et al. 2005, Ramseier Peter et al. 2011, Sharma 2013).

TABLE I. FACTORIAL DESIGN OF FERRATE ELECTROSYNTHESIS

\begin{tabular}{lccc}
\hline Factors & Symbol & $\begin{array}{c}\text { Level 1 } \\
(-)\end{array}$ & $\begin{array}{c}\text { Level 2 } \\
(+)\end{array}$ \\
\hline Electrolyte type & $\mathrm{A}$ & $\mathrm{NaOH}$ & $\mathrm{KOH}$ \\
Electrolyte concentration $(\mathrm{M})$ & $\mathrm{B}$ & 14 & 20 \\
Current density $\left(\mathrm{mA} / \mathrm{cm}^{2}\right)$ & $\mathrm{C}$ & 30 & 100 \\
Temperature $\left({ }^{\circ} \mathrm{C}\right)$ & $\mathrm{D}$ & 4 & $\mathrm{RT}$ \\
\hline
\end{tabular}

(-) low level, (+) high level, (RT) room temperature

\section{Characterization of ferrate (VI)}

Ferrate(VI) was characterized by three analytical techniques: a) infrared spectroscopy (IR) to observe the characteristic functional groups at 324 and $8001 /$ $\mathrm{cm}$; b) cyclic voltammetry (CV), an electroanalytical technique used for the determination of compounds that are oxidized or reduced electrochemically, and c) ultraviolet-visible spectroscopy (UV-Vis), which provides information via the characteristic absorption peak at $505 \mathrm{~nm}$.

\section{Indigo blue aqueous solutions}

Indigo blue dye was obtained from an industrial dyeing operation located in the State of Mexico, and was characterized using IR spectroscopy and UV-Vis spectroscopy in a previous report (Almazán-Sánchez et al. 2016). For this, 10, 30, 40, 50, and $100 \mathrm{mg} / \mathrm{L}$ aqueous solutions of the dye were prepared $(\mathrm{pH}=$ 8.0 ), and the concentration was determined by UVVis spectrometry at $591 \mathrm{~nm}$, based on the previous results.

\section{Textile wastewater sample}

A wastewater sample from the effluent of an industrial textile operation located in the State of Mexico was collected in plastic containers. The following parameters of the sample were analyzed: temperature, biochemical oxygen demand $\left(\mathrm{BOD}_{5}\right)$, chemical oxygen demand (COD), total organic carbon (TOC), color (Pt-Co units), turbidity, $\mathrm{pH}$, sulfates $\left(\mathrm{SO}_{4}{ }^{2-}\right)$, ammonia nitrogen $\left(\mathrm{NH}_{4}{ }^{+}\right)$, total suspended solids (TSS), methylene blue active substances (MBAS), nitrates $\left(\mathrm{NO}_{3}{ }^{-}\right)$, nitrites $\left(\mathrm{NO}_{2}^{-}\right)$, total phosphorus, total solids (TS), total dissolved solids (TDS), oil and grease, residual chlorine, magnesium, sodium, and calcium, according to standard methods and procedures (APHA 2012). The sample was also analyzed using IR spectroscopy and UV-Vis to determine the mechanism of dye removal. The same parameters were analyzed in the treated wastewater in order to evaluate the efficiency of ferrate.

\section{Treatment of the aqueous solutions and wastewa- ter by sodium and potassium ferrate}

A jar test was used to determine the optimum time and ferrate dose for the treatment of the aqueous solutions and denim wastewater. Batch experiments were carried out by combining $8 \mathrm{~mL}$ of the indigo blue aqueous solutions with different initial concentrations $(10,30,40,50$, or $100 \mathrm{mg} / \mathrm{L})$ with $25,50,100,200$, or $300 \mathrm{mg} / \mathrm{L}$ of previously synthesized potassium and sodium ferrate. The solutions were mixed rapidly $(250 \mathrm{rpm})$ for $1 \mathrm{~min}$, and then at a lower rate $(50 \mathrm{rpm})$ for $26 \mathrm{~h}$. Aliquots were collected at different times $(1,2,3,4,5,6,7$, and $26 \mathrm{~h})$ and the concentration of indigo blue was evaluated in order to calculate the removal percentage at the end of the treatment. For the denim wastewater, the treatments were carried 
out under the same conditions, and the color removal efficiency was evaluated after $1 \mathrm{~h}$. All experiments were carried out in triplicate.

\section{RESULTS AND DISCUSSION}

\section{Electrochemical synthesis of ferrate}

The effect of different variables in the electrosynthesis of ferrate was evaluated using a $2^{4}$ factorial design. The effect of each factor was analyzed separately in order to determine its influence on the process. Table II shows the optimal operational conditions for the electrochemical processes. According to the results, the best ferrate yield was obtained in experiment 15 , using $20 \mathrm{M} \mathrm{NaOH}$, and applying a current density of $100 \mathrm{~mA} / \mathrm{cm}^{2}$ at room temperature $\left(25^{\circ} \mathrm{C}\right)$.

Figure 1 shows that the highest production of ferrate was achieved by applying a current density of $100 \mathrm{~mA} / \mathrm{cm}^{2}$, with the yield of ferrate reaching $6.89 \mathrm{~g} / \mathrm{L}(41.54 \mathrm{mM})$. At a current density of $30 \mathrm{~mA} / \mathrm{cm}^{2}$, only $2.31 \mathrm{~g} / \mathrm{L}(13.92 \mathrm{mM})$ of ferrate was synthesized using $\mathrm{NaOH}$ as the electrolyte, as shown in table II. Many studies have reported the synthesis of ferrate under different experimental conditions, some of which obtained 2.03, 1.91, and $1.74 \mathrm{mM}$ of ferrate in $20 \mathrm{M} \mathrm{NaOH}$ media with current densities of 4.55, 3.08 , and $1.47 \mathrm{~mA} / \mathrm{cm}^{2}$, respectively (Barışç1 et al. 2014). Alsheyab et al. (2010) achieved concentrations in the range $0.54-3.25 \mathrm{mM}$ by applying current densities from 1.8 to $18.1 \mathrm{~mA} / \mathrm{cm}^{2}$ in $14 \mathrm{M} \mathrm{NaOH}$. Other authors achieved yields of 7.3 and $1.5 \mathrm{mM}$ at 3.3 and $0.5 \mathrm{~mA} / \mathrm{cm}^{2}$ in $16 \mathrm{M} \mathrm{NaOH}$ (Ding et al. 2004). Finally, a concentration of approximately $0.23 \mathrm{mM}$ was achieved at $125 \mathrm{~mA} / \mathrm{cm}^{2}$ using $14 \mathrm{M}$ KOH (Sánchez-Carretero et al. 2010).

Different mechanisms have been proposed to explain the process of ferrate production in the electrochemical cell; equations 1-7 (Mácová et al. 2009) describe anodic dissolution and involve the formation of a passivating layer over the electrode, reducing the ferrate yield. This film consists of $\mathrm{FeOOH}$ and $\mathrm{Fe}(\mathrm{OH})_{2}$ (Eq. 2-3), which block the flow of electrons. Additionally, $\mathrm{Fe}_{3} \mathrm{O}_{4}$ (Eq. 1) can act as a barrier against further iron dissolution and prevent the formation of ferrate; it also competes with oxygen evolution (Eq. 7). The hydroxyl ions promote the reaction by dissolving the oxide/hydroxide layer, as shown in equations 4-6. Hydrogen gas is produced at the cathode in the global reaction (Barışç1 et al. 2014). The electrochemical reactions generated at the anode and cathode are shown in figure 2 (Zou and Chin 1988, Jiang and Lloyd 2002, Alsheyab et al. 2010).

TABLE II. RESULTS OF FERRATE SYNTHESIS, ACCORDING TO $2^{4}$ FACTORIAL DESIGN. STUDIED VARIABLES: A = ELECTROLYTE TYPE (NaOH OR KOH), B = ELECTROLYTE CONCENTRATION (14 AND $20 \mathrm{M}$ ), C = CURRENT DENSITY (30 AND $\left.100 \mathrm{MA} / \mathrm{CM}^{2}\right), \mathrm{D}=\mathrm{TEMPERATURE}\left(4^{\circ} \mathrm{C}\right.$ AND ROOM TEMPERATURE)

\begin{tabular}{|c|c|c|c|c|c|c|c|}
\hline \multirow[t]{2}{*}{ Experiment } & \multirow[t]{2}{*}{ Interaction } & \multicolumn{4}{|c|}{ Factors } & \multirow{2}{*}{$\begin{array}{c}\left(\mathrm{FeO}_{4}\right)^{2-} \\
(\mathrm{g} / \mathrm{L})\end{array}$} & \multirow{2}{*}{$\begin{array}{l}\text { Energy consumption } \\
(\mathrm{kWh} / \mathrm{kg})\end{array}$} \\
\hline & & A & $\begin{array}{c}\mathrm{B} \\
(\mathrm{M})\end{array}$ & $\begin{array}{c}\mathrm{C} \\
\left(\mathrm{mA} / \mathrm{cm}^{2}\right)\end{array}$ & $\begin{array}{c}\mathrm{D} \\
\left({ }^{\circ} \mathrm{C}\right)\end{array}$ & & \\
\hline 1 & $\mathrm{M}^{*}$ & $\mathrm{NaOH}$ & 14 & 30 & 4 & 0.20 & 10.86 \\
\hline 2 & A & $\mathrm{KOH}$ & 14 & 30 & 4 & 0.04 & 44.86 \\
\hline 3 & B & $\mathrm{NaOH}$ & 20 & 30 & 4 & 1.42 & 1.53 \\
\hline 4 & $\mathrm{AB}$ & $\mathrm{KOH}$ & 20 & 30 & 4 & 0.05 & 37.81 \\
\hline 5 & $\mathrm{C}$ & $\mathrm{NaOH}$ & 14 & 100 & 4 & 0.81 & 17.03 \\
\hline 6 & $\mathrm{AC}$ & $\mathrm{KOH}$ & 14 & 100 & 4 & 0.15 & 90.43 \\
\hline 7 & $\mathrm{BC}$ & $\mathrm{NaOH}$ & 20 & 100 & 4 & 0.58 & 12.50 \\
\hline 8 & $\mathrm{ABC}$ & $\mathrm{KOH}$ & 20 & 100 & 4 & 0.33 & 27.24 \\
\hline 9 & $\mathrm{D}$ & $\mathrm{NaOH}$ & 14 & 30 & RT & 1.32 & 1.65 \\
\hline 10 & $\mathrm{AD}$ & $\mathrm{KOH}$ & 14 & 30 & RT & 0.25 & 5.69 \\
\hline 11 & BD & $\mathrm{NaOH}$ & 20 & 30 & RT & 2.31 & 0.63 \\
\hline 12 & $\mathrm{ABD}$ & $\mathrm{KOH}$ & 20 & 30 & RT & 0.20 & 6.89 \\
\hline 13 & $\mathrm{CD}$ & $\mathrm{NaOH}$ & 14 & 100 & RT & 1.38 & 4.43 \\
\hline 14 & $\mathrm{ACD}$ & $\mathrm{KOH}$ & 14 & 100 & RT & 0.42 & 21.94 \\
\hline 15 & $\mathrm{BCD}$ & $\mathrm{NaOH}$ & 20 & 100 & RT & 6.89 & 2.01 \\
\hline 16 & $\mathrm{ABCD}$ & $\mathrm{KOH}$ & 20 & 100 & RT & 0.31 & 44.49 \\
\hline
\end{tabular}

* $\mathrm{M}$ is the standard order. It refers to the experiment in which all the variables are in the low level, $\mathrm{RT}=$ room temperature 


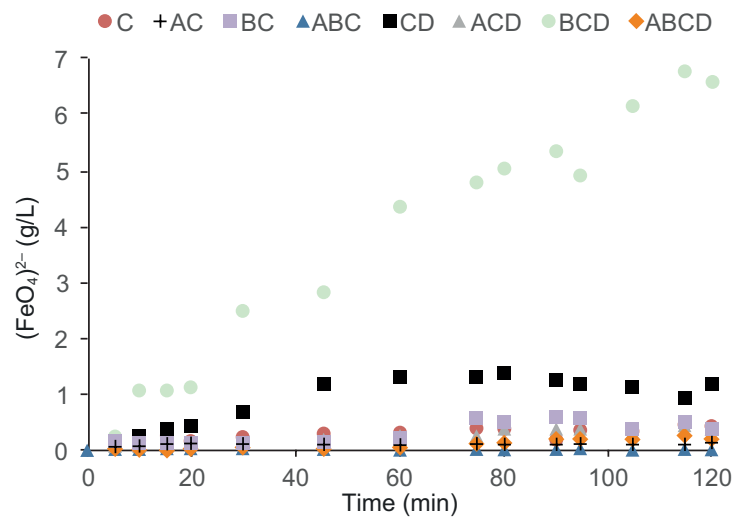

a)

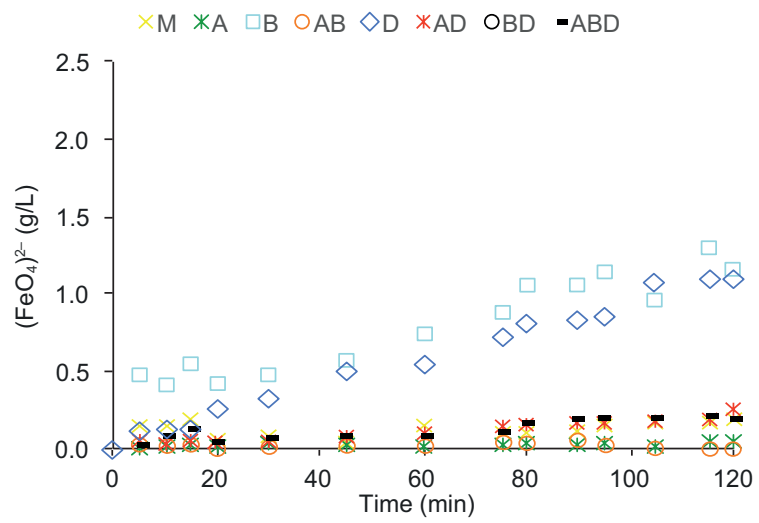

b)

Fig 1. Current density effect. a) $100 \mathrm{~mA} / \mathrm{cm}^{2}$, b) $30 \mathrm{~mA} / \mathrm{cm}^{2}$. Electrolyte type (A), electrolyte concentration (B), current density (C) and temperature (D)

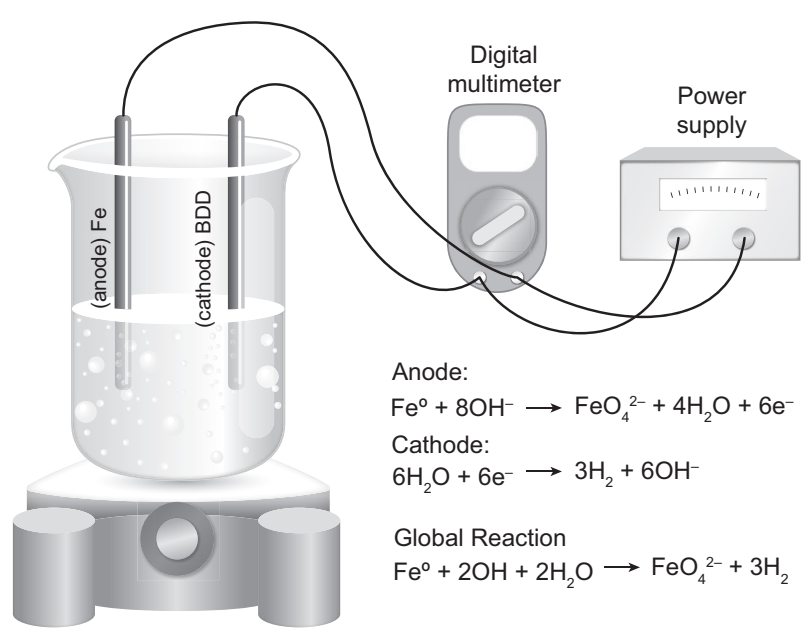

Fig 2. Electrochemical synthesis of ferrate (VI)

The sacrificial iron anode is oxidized from iron (0) to iron (VI) in the presence of hydroxyl ions, and simultaneous oxygen evolution and gas production take place. The energy consumption of the reaction was $2.01 \mathrm{KWh} / \mathrm{kg}$, which was in agreement with the report of Barışç1 et al. (2014).

$$
\begin{aligned}
& 3 \mathrm{Fe}^{\circ}+8 \mathrm{OH}^{-} \rightarrow \mathrm{Fe}_{3} \mathrm{O}_{4}+4 \mathrm{H}_{2} \mathrm{O}+8 \mathrm{e}^{-} \\
& \mathrm{Fe}^{\circ}+2 \mathrm{OH}^{-} \rightarrow \mathrm{Fe}(\mathrm{OH})_{2}+2 \mathrm{e}^{-} \\
& \mathrm{Fe}(\mathrm{OH})_{2}+\mathrm{OH}^{-} \rightarrow \mathrm{FeOOH}+\mathrm{H}_{2} \mathrm{O}+\mathrm{e}^{-} \\
& \mathrm{FeOOH}+\mathrm{OH}^{-} \rightarrow \mathrm{FeO}_{2}^{-}+\mathrm{H}_{2} \mathrm{O}
\end{aligned}
$$

$$
\begin{aligned}
& \mathrm{FeO}_{2}^{-}+2 \mathrm{OH}^{-} \rightarrow \mathrm{FeO}_{3}{ }^{2-}+\mathrm{H}_{2} \mathrm{O}+\mathrm{e}^{-} \\
& 3 \mathrm{FeO}_{3}{ }^{2-}+\mathrm{H}_{2} \mathrm{O} \rightarrow 2 \mathrm{FeO}_{2}^{-}+\mathrm{FeO}_{4}{ }^{2-}+2 \mathrm{OH}^{-} \\
& 2 \mathrm{OH}^{-} \rightarrow \mathrm{H}_{2} \mathrm{O}+1 / 2 \mathrm{O}_{2}+2 \mathrm{e}^{-}
\end{aligned}
$$

The type of electrolyte used affects iron dissolution, the formation of the oxide/hydroxide layer, and the solubility of the dissolution products. Some researchers have suggested that $\mathrm{NaOH}$ is the best electrolyte for the electrochemical preparation of ferrate (Bouzek et al. 1999, Bouzek and Bergmann 1999, Ding et al. 2004, Xu et al. 2009, Barışç et al. 2014), while others have reported that better electrosynthesis results were obtained using $\mathrm{KOH}$ (He et al. 2005). $\mathrm{Na}_{2} \mathrm{FeO}_{4}$ remains soluble in saturated aqueous $\mathrm{NaOH}$ solutions, but $\mathrm{K}_{2} \mathrm{FeO}_{4}$ is insoluble in a saturated $\mathrm{KOH}$ solution (Jiang and Lloyd 2002). In this study, $\mathrm{NaOH}$ was found to be the best alkaline medium, as shown in figure $\mathbf{3} \mathbf{a}$ and $\mathbf{3 b}$. When $\mathrm{KOH}$ was used, only $0.42 \mathrm{~g} / \mathrm{L}$ of ferrate was produced.

According to the previous equations, ferrate production increases with increasing $\mathrm{HO}^{-}$ion concentration. A concentrated medium increases the solubility of lower-valence iron species and promotes ferrate stability (Zou and Chin 1988, He et al. 2006, Mácová et al. 2009). When KOH is used at high concentrations (over $500 \mathrm{~g} / \mathrm{L}$ ), the oxides and hydroxides formed crystalize on the anode surface (Bouzek et al. 1999). In this research, concentrations of $14 \mathrm{M}$ and $20 \mathrm{M}$ were evaluated. Using $20 \mathrm{M} \mathrm{NaOH}$, the maximum ferrate concentration of $6.89 \mathrm{~g} / \mathrm{L}$ was obtained (Fig. 3c), while a concentration of $1.38 \mathrm{~g} / \mathrm{L}$ was obtained using $14 \mathrm{M} \mathrm{NaOH}$ (Fig. 3d). 


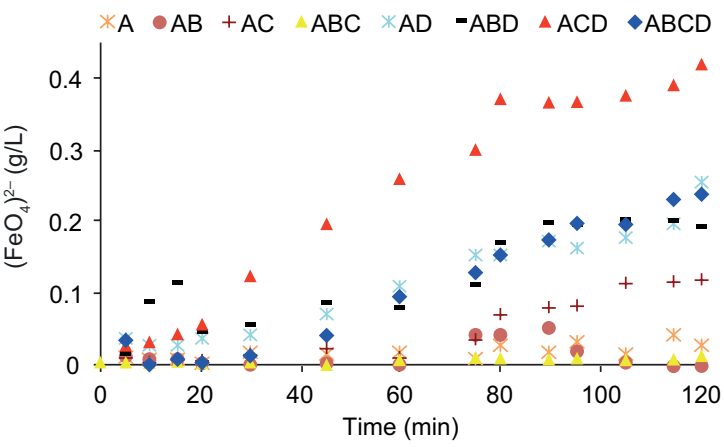

a)

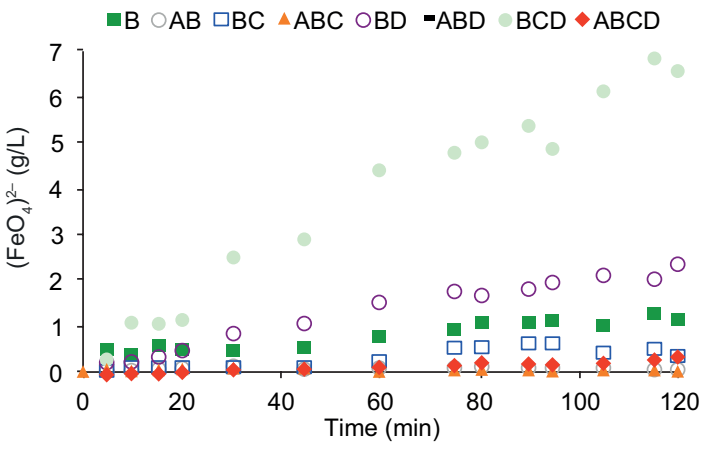

c)

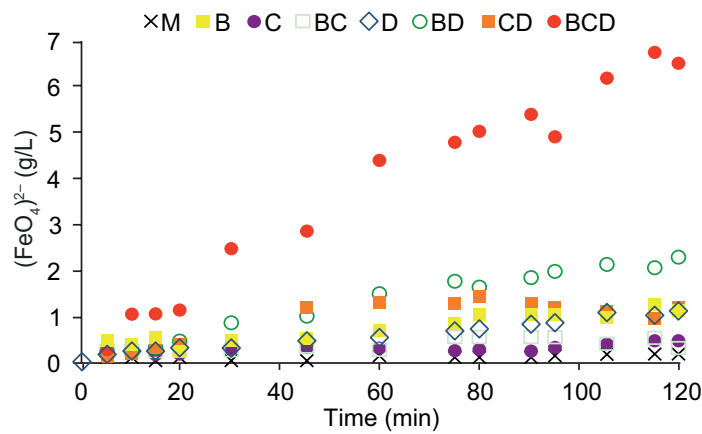

b)

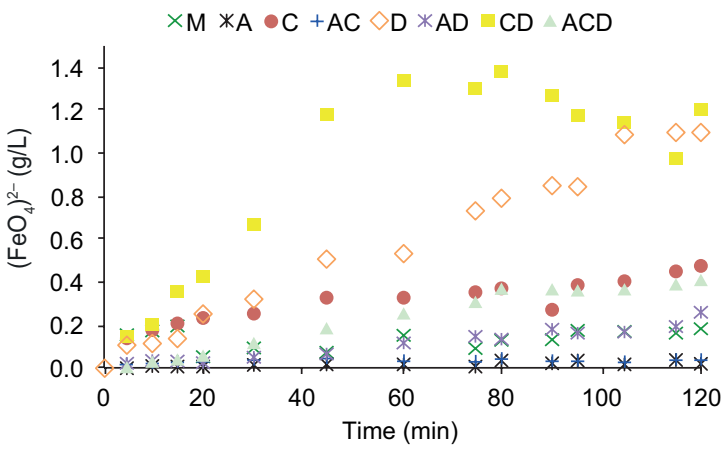

d)

Fig 3. Electrolyte effect. a) $\mathrm{KOH}$ (concentration of electrolyte: 14 and $20 \mathrm{M}$, current density: 30 and $100 \mathrm{~mA} / \mathrm{cm}^{2}, \mathrm{~T}=4^{\circ} \mathrm{C}$ and room temperature), b) $\mathrm{NaOH}$ (concentration of electrolyte: 14 and $20 \mathrm{M}$, current density: 30 and $100 \mathrm{~mA} / \mathrm{cm}^{2}$, $\mathrm{T}=4{ }^{\circ} \mathrm{C}$ and room temperature), c) $20 \mathrm{M}$ (electrolyte: $\mathrm{NaOH}$ and $\mathrm{KOH}$, current density: 30 and $100 \mathrm{~mA} / \mathrm{cm}^{2}, \mathrm{~T}=$ $4{ }^{\circ} \mathrm{C}$ and room temperature), d) $14 \mathrm{M}$ (electrolyte: $\mathrm{NaOH}$ and $\mathrm{KOH}$, current density: 30 and $100 \mathrm{~mA} / \mathrm{cm}^{2}, \mathrm{~T}=4^{\circ} \mathrm{C}$ and room temperature). Electrolyte type (A), electrolyte concentration (B), current density (C) and temperature (D)

Changing the temperature could induce the depassivation of the anode surface. The influence of temperature on electrochemical ferrate production has previously been reported by several researchers (Beck et al. 1985). For instance, Barış̧̧1 et al. (2014) studied the effect of using temperatures of 20, 30, 50, and $65^{\circ} \mathrm{C}$ with high-purity iron anodes. The highest production rate after $75 \mathrm{~min}$ was obtained at $65^{\circ} \mathrm{C}$, and the lowest production rate was observed at $20^{\circ} \mathrm{C}$. They concluded that higher temperatures led to better production in ferrate synthesis using high-purity iron anodes. In this work, similar behavior was observed; the maximum ferrate concentration was achieved at room temperature $\left(25^{\circ} \mathrm{C}\right)$, whereas at $4{ }^{\circ} \mathrm{C}$, only $1.42 \mathrm{~g} / \mathrm{L}$ was obtained (Fig. 4).

The results were validated using the Yates algorithm to explain the synergic effect of all the operational variables. The Yates equation obtained is as follows:

$\mathrm{Y}=1.03-1.63 \mathrm{~A}+0.98 \mathrm{~B}+0.54 \mathrm{C}+1.09 \mathrm{D}$

Where:
$\mathrm{A}($ type of electrolyte $)=-1.63 \mathrm{~g} / \mathrm{L}, \mathrm{B}$ (concentration of electrolyte $)=0.98 \mathrm{~g} / \mathrm{L}, \mathrm{C}($ current density $)=0.54 \mathrm{~g} / \mathrm{L}$, and $\mathrm{D}($ temperature $)=1.09 \mathrm{~g} / \mathrm{L}$.

Based on the electrolyte type parameter (A), changing the electrolyte from $\mathrm{NaOH}$ electrolyte to $\mathrm{KOH}$ reduced the ferrate concentration. When the concentration of electrolyte (B) was increased from 14 to $20 \mathrm{M}$, the synthesis of ferrate was enhanced. Increasing the current density (C) from 30 to 100 $\mathrm{mA} / \mathrm{cm}^{2}$ had a positive effect on the electrochemical process, improving the production of ferrate. Increasing the temperature (D) from $4{ }^{\circ} \mathrm{C}$ to room temperature $\left(25^{\circ} \mathrm{C}\right)$ also enhanced the concentration of ferrate.

Table III shows the effects calculated by the Yates algorithm; through these data, the sum of squares, estimated coefficients, standard deviation and the "F" test were determined. Variables B, C and D have effects on both levels in the electrochemical synthesis of ferrate (VI); while the variable A (type of electrolyte) is optimal with $\mathrm{NaOH}$ at the low level.

In conclusion, the maximum experimental concentration of ferrate produced in $180 \mathrm{~min}$ was 

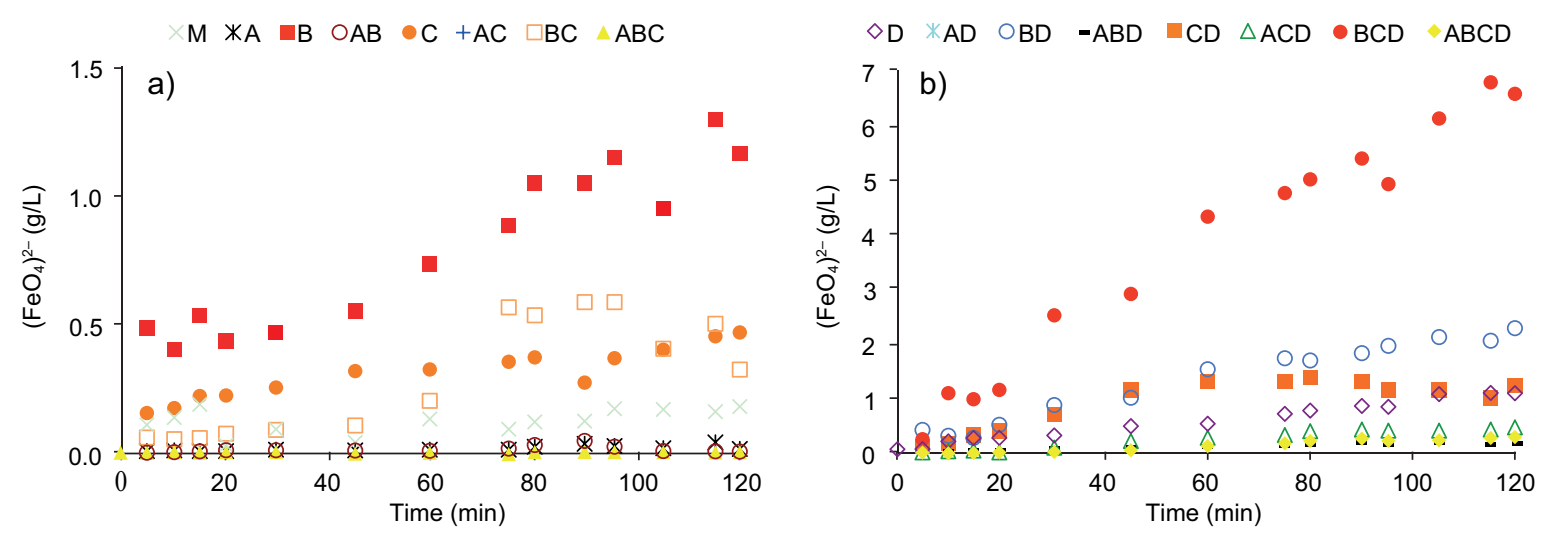

Fig 4. Temperature effect. a) $4^{\circ} \mathrm{C}$, b) room temperature. Electrolyte type (A), electrolyte concentration (B), current density (C) and temperature (D)

TABLE III. STATISTICAL ANALYSIS IN THE ELECTROCHEMICAL SYNTHESIS OF FERRATE

\begin{tabular}{lrrcrr}
\hline Interaction & Effect & $\begin{array}{c}\text { Sum of } \\
\text { squares }\end{array}$ & $\begin{array}{c}\text { Estimated } \\
\text { coefficients }\end{array}$ & $\begin{array}{c}\text { Standard } \\
\text { deviation }\end{array}$ & "F" Test \\
\hline M & 1.03 & & & 0.44 & 2.96 \\
A & -1.64 & 10.73 & -0.82 & 0.44 & -1.86 \\
B & 0.93 & 3.47 & 0.47 & 0.44 & 1.06 \\
AB & -0.97 & 3.76 & -0.48 & 0.44 & -1.10 \\
C & 0.60 & 1.43 & 0.30 & 0.44 & 0.68 \\
AC & -0.48 & 0.90 & -0.24 & 0.44 & -0.54 \\
BC & 0.41 & 0.66 & 0.20 & 0.44 & 0.46 \\
ABC & -0.33 & 0.44 & -0.17 & 0.44 & -0.38 \\
D & 1.15 & 5.29 & 0.58 & 0.44 & 1.31 \\
AD & -1.04 & 4.35 & -0.52 & 0.44 & -1.19 \\
BD & 0.65 & 1.71 & 0.33 & 0.44 & 0.74 \\
ABD & -0.70 & 1.94 & -0.35 & 0.44 & -0.79 \\
CD & 0.63 & 1.60 & 0.32 & 0.44 & 0.72 \\
ACD & -0.61 & 1.51 & -0.31 & 0.44 & -0.70 \\
BCD & 0.91 & 3.32 & 0.46 & 0.44 & 1.04 \\
ABCD & -0.81 & 2.63 & -0.41 & 0.44 & -0.92 \\
\hline
\end{tabular}

$6.89 \mathrm{~g} / \mathrm{L}$, using $20 \mathrm{M} \mathrm{NaOH}$, a current density of $100 \mathrm{~mA} / \mathrm{cm}^{2}$, and room temperature $\left(25^{\circ} \mathrm{C}\right)$.

\section{Ferrate characterization}

Ferrate (VI) has a characteristic purple-violet color, which corresponds to a visible and nearinfrared absorption spectrum from about 450 to $600 \mathrm{~nm}$. Figure 5a shows the UV/Vis spectra of electrogenerated $\mathrm{Na}_{2} \mathrm{FeO}_{4}$ and $\mathrm{K}_{2} \mathrm{FeO}_{4}$ in $20 \mathrm{M}$ media. The spectra of both ferrates showed maximum absorption at $505 \mathrm{~nm}$. These spectra were compared with that of a commercial ferrate, and were found to contain the same features. These results agree with those of Licht et al. (2001), Jiang and Lloyd (2002) and Barışçı et al. (2014), who all observed the same wavelength for ferrate.
In addition, ferrates have also been characterized using Fourier transform infrared (FTIR) spectra, in which they display characteristic absorption bands at 925 and $523 \mathrm{~cm}^{-1}$ in the infrared region with triplet splitting (Fig. 5b; Sharma 2013).

Finally, the cyclic voltammetry (CV) technique was used to determine the redox behavior of the different compounds. Figure 5c shows the $\mathrm{CV}$ obtained at a scan rate of $100 \mathrm{mV} / \mathrm{s}$ using $\mathrm{Ag} / \mathrm{AgCl}$ as the reference electrode, iron as the working electrode, and carbon paste as the counter electrode. Curve "a" shows only the $20 \mathrm{M} \mathrm{NaOH}$. In curves "b," "c," and "d," different concentrations of ferrate were added, and four peaks were obtained; the peaks numbered 1 and 2 correspond to the redox pair $\mathrm{Fe}^{2+} / \mathrm{Fe}^{3+}$. This pair exhibits a quasi-reversible one-electron charge 

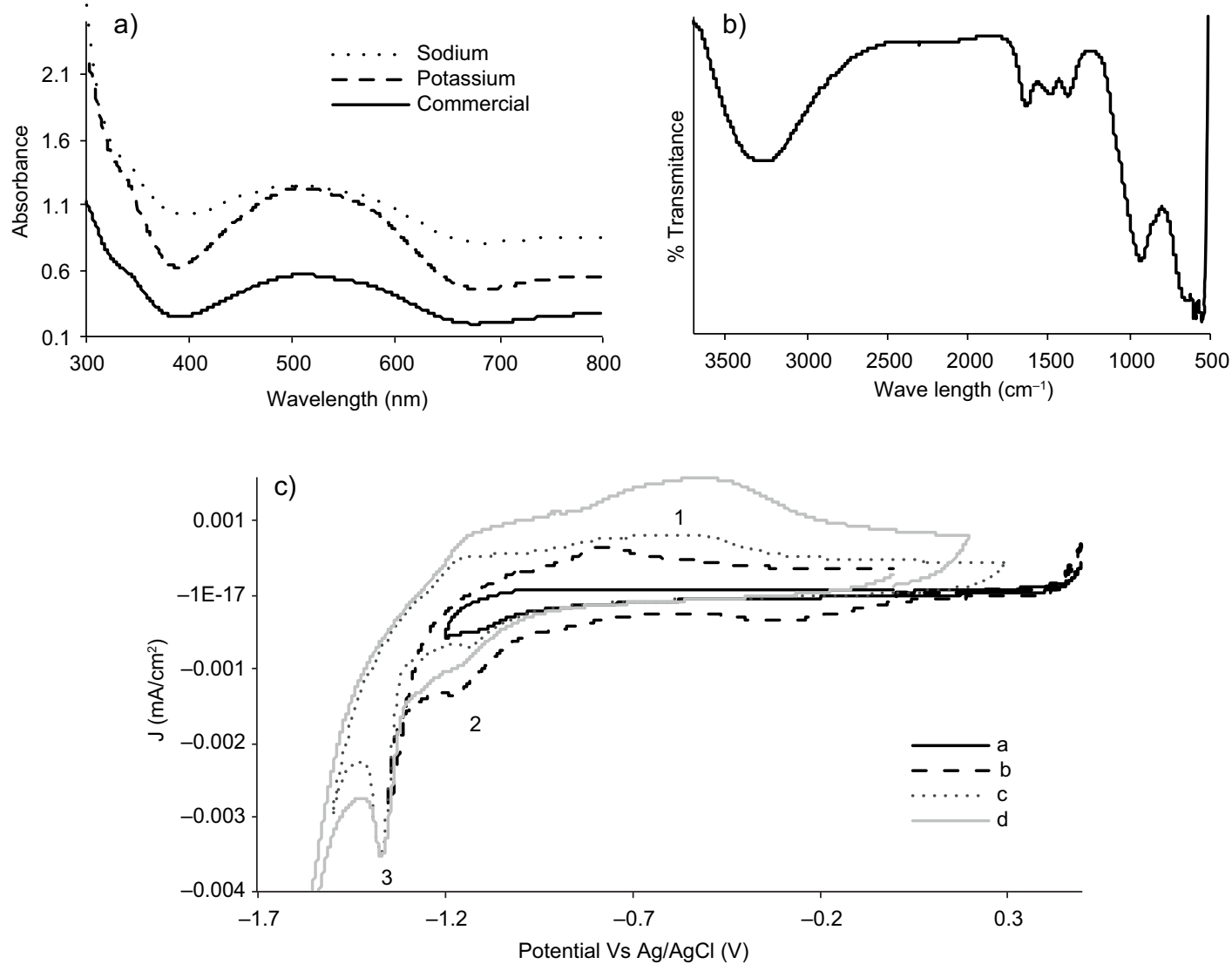

Fig 5. Ferrate characterization: a) ultraviolet visible spectra, b) infrared spectra, c) cyclic voltammetry ("a" $\mathrm{NaOH}$ $20 \mathrm{M}$, "b," "c," and "d": 1, 2 and $3 \mathrm{~mL}$ of ferrate were added)

transfer, while peak 3 is associated with the ferrate ion formation at $-1.36 \mathrm{~V}$ (Licht et al. 2001, de Koninck and Bélanger 2003, Barışç1 et al. 2014).

\section{Aqueous solution treatment (Jar test)}

The dye removal percentages for the aqueous indigo blue solutions using $\mathrm{Na}_{2} \mathrm{FeO}_{4}$ and $\mathrm{K}_{2} \mathrm{FeO}_{4}$ are presented in figure 6. The maximum dye removal percentages (over $77 \%$ ) were achieved using Na${ }_{2} \mathrm{FeO}_{4}(300 \mathrm{mg} / \mathrm{L}$ dose $)$ for all dye concentrations, while only 94 and $96 \%$ dye removal was achieved for 20 and $30 \mathrm{mg} / \mathrm{L}$ dye concentrations at a dose of $200 \mathrm{mg} / \mathrm{L}$. $\mathrm{Na}_{2} \mathrm{FeO}_{4}$ showed the better results at high doses only (Fig. 6a). Based on these results, the removal percentage strongly depends on the dose of ferrate. Very high doses of ferrate proved to be the most effective in reducing the organic concentration, because for a given volume of solution, proportionally increasing the quantity of the reactants could promote the probability of collision between the target pollutant and the oxidant, leading to an increase in the degradation efficiency (Jiang 2007, Han et al. 2013).
As shown in figure $\mathbf{6 b}, \mathrm{K}_{2} \mathrm{FeO}_{4}$ was superior at low dye concentrations $(10,20$, and $30 \mathrm{mg} / \mathrm{L})$ using intermediate doses. When the dye concentration was $10 \mathrm{mg} / \mathrm{L}$, doses of 25,50 , and $100 \mathrm{mg} / \mathrm{L}$ of $\mathrm{K}_{2} \mathrm{FeO}_{4}$ gave the best dye removal results $(76.9,79.5$, and $87.5 \%$ respectively). Using dye concentrations of 20 and $30 \mathrm{mg} / \mathrm{L}$ and a ferrate dose of $200 \mathrm{mg} / \mathrm{L}$, around $70 \%$ color removal was achieved. When the ferrate dose was increased to $300 \mathrm{mg} / \mathrm{L}, 90 \%$ color removal was achieved. Li et al. (2009) treated a $50 \mathrm{mg} / \mathrm{L}$ aqueous solution of an azo dye (orange II) with $10 \mathrm{mg} / \mathrm{L} \mathrm{K}_{2} \mathrm{FeO}_{4}$ and $62 \%$ color removal was obtained. Xu et al. (2009) treated the azo dye $\mathrm{X}-3 \mathrm{~B}$ red in aqueous solution (initial concentration $0.08 \mathrm{mM}$ ) with $25 \mathrm{mg} / \mathrm{L} \mathrm{K}_{2} \mathrm{FeO}_{4}$, achieving $95 \%$ color removal at $\mathrm{pH} 10$.

Ferrate ion is a strong oxidant over the entire $\mathrm{pH}$ range: Its redox potentials are 2.20 and $0.72 \mathrm{~V}$ in acidic and basic media (Eqs. 9-10), respectively.

$\mathrm{FeO}_{4}{ }^{2-}+8 \mathrm{H}^{+}+3 \mathrm{e}^{-} \rightarrow \mathrm{Fe}^{3+}+4 \mathrm{H}_{2} \mathrm{O} \quad \mathrm{E}^{\circ}=2.2 \mathrm{~V}$ 

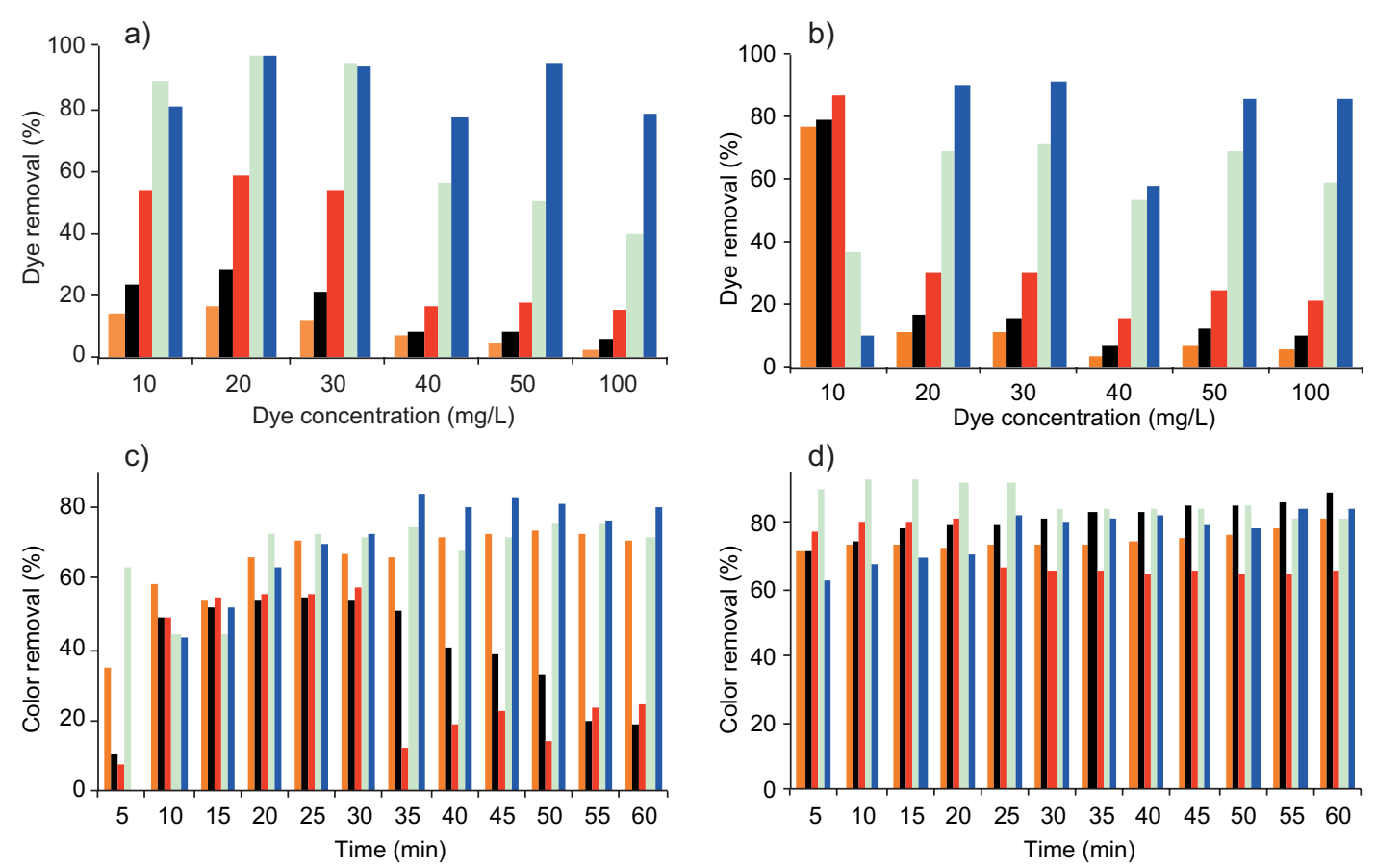

$=25 \mathrm{mg} / \mathrm{L} \quad \square 50 \mathrm{mg} / \mathrm{L} \quad \square 100 \mathrm{mg} / \mathrm{L} \quad 200 \mathrm{mg} / \mathrm{L} \quad \square 300 \mathrm{mg} / \mathrm{L}$

Fig 6. Removal percentage. Aqueous solution: a) sodium ferrate, b) potassium ferrate. Denim wastewater: c) sodium ferrate, $d$ ) potassium ferrate

$\mathrm{FeO}_{4}{ }^{2-}+4 \mathrm{H}_{2} \mathrm{O}+3 \mathrm{e}^{-} \rightarrow \mathrm{Fe}(\mathrm{OH})_{3}+5 \mathrm{OH}^{-}$

$\mathrm{E}^{\circ}=0.7 \mathrm{~V}$

The $\mathrm{pH}$ has a great effect on the decolorization of indigo blue dye by ferrate (Li et al. 2009, Xu et al. 2009) due to its effect on the redox potential and ferrate stability. The oxidation potential of ferrate decreases with increasing $\mathrm{pH}$, because although ferrate is a more powerful oxidant at $\mathrm{pH}<6$, it is also highly unstable under these acidic conditions. Conversely, it becomes more chemically stable but has a weaker oxidizing ability at $\mathrm{pH}>9$. Thus, the optimum $\mathrm{pH}$ range is 6-9; the removal efficiency is low above and below this $\mathrm{pH}$. In the experiments, the $\mathrm{pH}$ was increased to $11-12$, as increasing the $\mathrm{pH}$ can cause the hydrolysis of Fe compounds to $\mathrm{Fe}(\mathrm{OH})_{3}$ (aq) or colloids, which are capable of adsorbing dye molecules and removing them from the solution.

In the current research, testing was carried out at room temperature. However, in accordance with the report of Han et al. (2013), increasing the temperature of the reaction medium would enhance the probability of collision between the target pollutant and oxidizing agent, and thus accelerate the reaction rate.
Figure 7 shows the possible mechanisms for the oxidation of denim blue by ferrate. In the first step, the destabilization of the first N-H bond occurs in the presence of ferrate, free radicals are formed, and ferrate is reduced from $\mathrm{Fe}(\mathrm{VI})$ to $\mathrm{Fe}(\mathrm{V})$. In the next step, the destabilization of the second N-H bond occurs through $\mathrm{FeO}_{4}^{-}$, and a conjugated double bond is formed. Then, the decomposition of $\mathrm{FeO}_{4}{ }^{-}$to $\mathrm{Fe}(\mathrm{OH})_{3}$ and $\mathrm{O}_{2}$ in the basic media $\left(\mathrm{OH}^{-}\right)$occurs, and the interaction between oxygen and water breaks the conjugated bond, regenerating the basic media. Finally, organic by-products are formed. Oxidation and coagulation are thus the main mechanisms of the dye removal process.

\section{Denim wastewater \\ Denim wastewater characterization}

An effluent sample was collected from an industrial textile operation located in the State of Mexico, which operates in batch processes with an effluent volume of $11600 \mathrm{~L} / \mathrm{d}$. The most significant parameters were determined before treatment and are shown in table IV. The wastewater generated by the textile industry includes cleaning wastewater, process wastewater, noncontact cooling wastewater, 

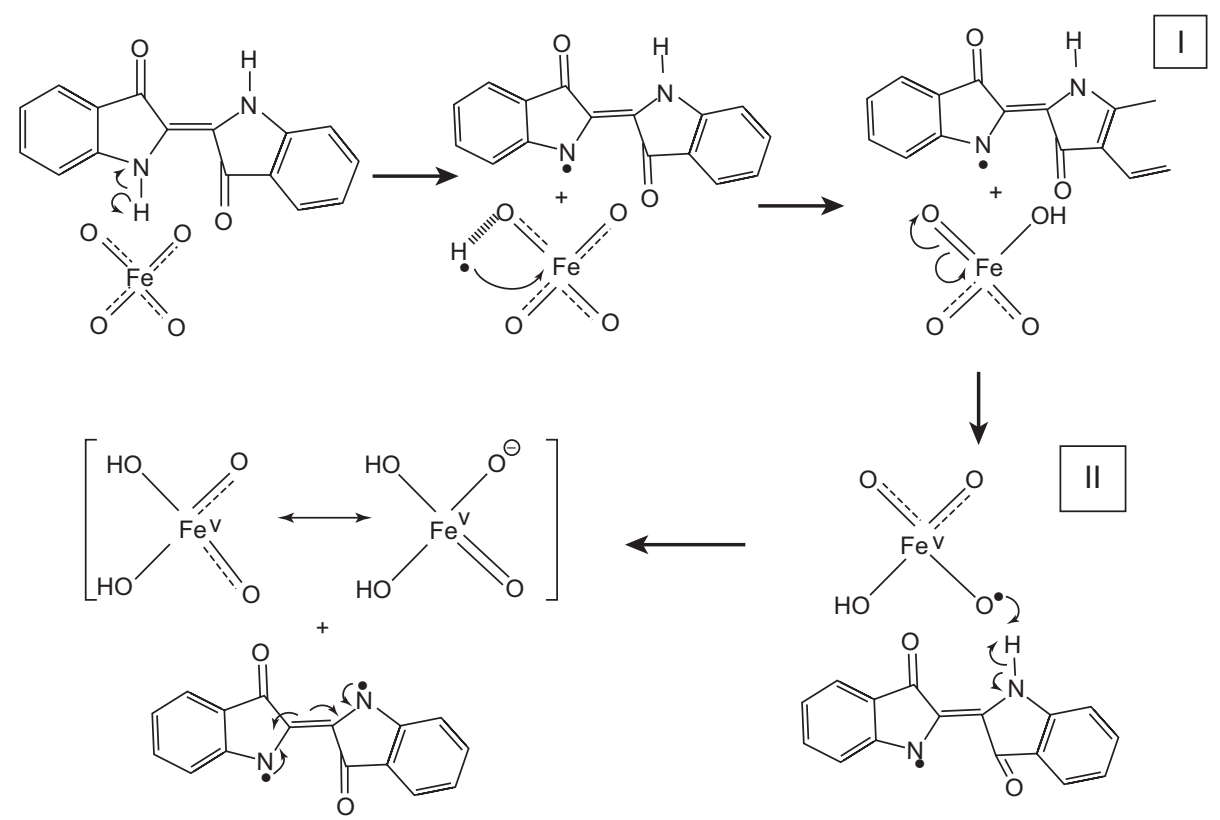<smiles>CN1C(=C2C(=O)c3ccccc3C2=O)Nc2ccccc21</smiles><smiles>CC</smiles><smiles>C/C=C\C1CC(=O)C(C2=N/C(=C\C)C(=O)C2=O)=N1</smiles>

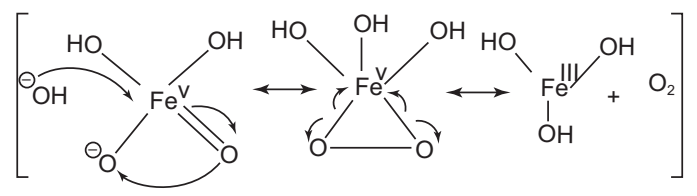

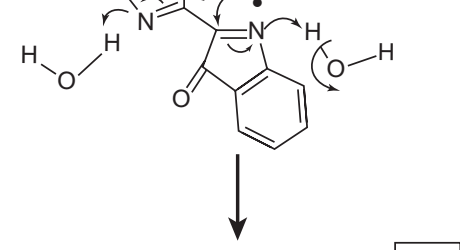

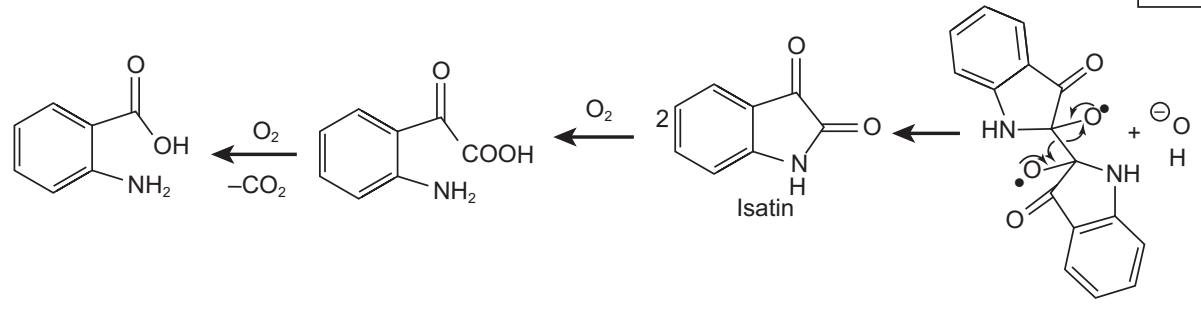

Fig 7. Mechanism of indigo blue removal

and storm water (Verma et al. 2012). The effluent from the denim processing is discharged into sewers and flushed into a local lagoon. The presence of nitrites in the water indicated biochemical and bacterial contamination. The high $\mathrm{NH}_{4}{ }^{+}$, residual chlorine, and phosphate ions $\left(\mathrm{PO}_{4}{ }^{3-}\right)$ concentration contribute to lagoon eutrophication and toxicity; the presence of grease reduces the dissolved oxygen and can cause fish death. According to Mexican regula- tions, the $\mathrm{PO}_{4}{ }^{3-}$, oil and grease, and TSS contents exceeded the allowed limits $(30,25$, and $125 \mathrm{mg} / \mathrm{L}$, respectively), and these levels reduced the visibility and increased the turbidity of the water. The $\mathrm{BOD}_{5} /$ COD index was 0.2. Finally, the $\mathrm{NO}_{3}{ }^{-}, \mathrm{PO}_{4}{ }^{3-}$, TSS, and $\mathrm{Mg}^{2+}$ levels were higher than the typical values given by Ciabatti et al. (2010). The chemical species diagrams were analyzed to determine the form of the chemicals in the denim wastewater, taking into 
TABLE IV. RAW AND TREATED DENIM WASTEWATER CHARACTERIZATION AND COMPARISON WITH TYPICAL VALUES FROM TEXTILE WASTEWATER

\begin{tabular}{lcccc}
\hline $\begin{array}{l}\text { Parameter } \\
(\mathrm{mg} / \mathrm{L})\end{array}$ & Initial & $\begin{array}{c}\text { Ciabatti et al. } \\
(2010)\end{array}$ & Final & Removal percentage \\
\hline Temperature & 18.2 & --- & 18 & --- \\
pH & 6.37 & $6.5-8.5$ & 11.47 & --- \\
Turbidity (NTU) & 178 & $15-200$ & 7.09 & 96.02 \\
Nitrates & 2.95 & $0.5-1.5$ & 1.48 & 50.16 \\
Total organic carbon & 680 & & 243.92 & 64.13 \\
Chemical oxygen demand & 734.13 & $550-1000$ & 320.9 & 56.29 \\
Sulfates & 118.73 & $400-600$ & 89.99 & 24.83 \\
Biochemical oxygen demand & 151.91 & --- & 315.30 & \\
Phosphates as P & 52.5 & $1-20$ & 42 & 20 \\
Ammonia nitrogen & 40 & --- & 19.8 & 50.5 \\
Color (Pt-Co) & 590 & --- & 75 & 92.51 \\
Nitrites & 3.33 & --- & 0.52 & 94.39 \\
Methylene blue active substances & 0.09 & --- & 0 & 100 \\
Total suspended solids & 405 & $100-400$ & 233 & 42.49 \\
Total dissolved solids & 1638 & --- & 1454.82 & 11.19 \\
Total solids & 2043 & --- & 1687.82 & 17.39 \\
Sodium & 89.30 & --- & 27.81 & 68.86 \\
Calcium & 9.42 & $40-100$ & 5.09 & 45.97 \\
Magnesium & 20.20 & $10-15$ & 0.87 & 95.7 \\
Residual chlorine & 1.3 & --- & 0 & 100 \\
Oil and grease & 26.8 & --- & 0 & 100 \\
\hline
\end{tabular}

account the concentration of the majority ions. The high concentrations of the ions $\mathrm{Na}^{+}, \mathrm{PO}_{4}{ }^{3-}, \mathrm{Mg}^{2+}$, $\mathrm{SO}_{4}{ }^{2-}, \mathrm{NO}_{3}{ }^{-}$, and $\mathrm{Ca}^{2+}$ promote the formation of $\mathrm{MgHPO}_{4}, \mathrm{MgSO}_{4}, \mathrm{CaSO}_{4}$, and $\mathrm{Ca}_{5}\left(\mathrm{PO}_{4}\right)_{3} \mathrm{OH}_{(\mathrm{s})}$ at the initial $\mathrm{pH}$, while $\mathrm{Na}^{+}, \mathrm{K}^{+}$, and $\mathrm{NO}_{3}{ }^{-}$remain in solution.

\section{Denim wastewater treatment}

The denim wastewater experiments were carried out using the same ferrate doses as those used for the aqueous solution. The maximum color removal was achieved during the first hour. The initial $\mathrm{pH}$ of the wastewater was 6.3. According to Ciabatti et al. (2010), the optimum $\mathrm{pH}$ range for the ferrate treatment of textile wastewater is 6.5-8.5, because the $\mathrm{pH}$ influences the molecular structure of dyes; that is, the dyes become protonated in acidic solution, which would induce the degradation process (Han et al. 2013). When the $\mathrm{pH}$ is higher, the oxidizing power of ferrate (VI) is lower, but the oxidation of water is much slower, which favors the oxidation of chemical species such as organic matter in the wastewater (Ciabatti et al. 2010).

As shown in figure $\mathbf{6 b}$ and $\mathbf{6 d}$, the optimum dose was $200 \mathrm{mg} / \mathrm{L} \mathrm{K}_{2} \mathrm{FeO}_{4}$, at which $92.51 \%$ color removal efficiency was reached in $30 \mathrm{~min}$. When the same dose of $\mathrm{Na}_{2} \mathrm{FeO}_{4}$ was added, the efficiency was only $72.85 \%$. Few works have reported the application of ferrate to real wastewater. Ciabati et al. (2010) treated textile wastewater using $70 \mathrm{mg} / \mathrm{L} \mathrm{K}_{2} \mathrm{FeO}_{4}$, and achieved removal efficiencies of $62 \%$ for COD, $70 \%$ for TSS, and $85 \%$ for turbidity. Gombos et al. (2013) applied 2-15 mg/L $\mathrm{Na}_{2} \mathrm{FeO}_{4}$ to a municipal secondary effluent and observed that the organic matter reduction was a function of ferrate concentration; efficiency removals of $15-60 \%$ of COD and 2-31\% of TOC were obtained. Since ferrate ions will be reduced to $\mathrm{Fe}(\mathrm{III})$ ions or $\mathrm{Fe}(\mathrm{OH})_{3}$ during the oxidation process, $\mathrm{Na}_{2} \mathrm{FeO}_{4}$ and $\mathrm{K}_{2} \mathrm{FeO}_{4}$ can act as coagulants. When the ferrate salts are dissolved in water, oxygen is evolved and ferric hydroxide precipitates from the solution; this makes the ferrate solution unstable (Eq. 9 ). Hence, this compound represents a unique dual function (oxidant and coagulant) chemical reagent that can be an effective alternative to current approaches for denim wastewater treatment.

$\mathrm{K}_{2} \mathrm{FeO}_{4}$ could be regenerated in water by the reaction of $\mathrm{Fe}(\mathrm{OH})_{3}$ with $\mathrm{KOH}$ and residual chlorine, as shown in equation 11 . In the denim wastewater, $1.3 \mathrm{mg} / \mathrm{L}$ of residual chlorine was detected. For this reason, $\mathrm{K}_{2} \mathrm{FeO}_{4}$ was more efficient than $\mathrm{Na}_{2} \mathrm{FeO}_{4}$.

$$
\begin{aligned}
& 2 \mathrm{Fe}(\mathrm{OH})_{3}+10 \mathrm{KOH}+3 \mathrm{Cl}_{2} \\
& \rightarrow 6 \mathrm{KCl}+8 \mathrm{H}_{2} \mathrm{O}+2 \mathrm{~K}_{2} \mathrm{FeO}_{4}
\end{aligned}
$$


In addition, the stability of ferrate in the effluent is significantly influenced by the initial ferrate concentration, pollutant concentration, $\mathrm{pH}$, temperature, and the concentrations of aqueous constituents, such as chloride, sulfate ions $\left(\mathrm{SO}_{4}{ }^{2-}\right)$, carbonate, and $\mathrm{NO}_{3}{ }^{-}$(Schroyer and Ockerman 1951, Sharma et al. 2010). The stability of ferrate solution increases with the presence of $\mathrm{KCl}, \mathrm{KNO}_{3}, \mathrm{PO}_{4}{ }^{3-}$, alkalinity, $\mathrm{Cl}^{-}$, $\mathrm{SO}_{4}{ }^{2-}$, and/or high $\mathrm{pH}$ values (Wagner et al. 1952). This could explain the differences in the treatment time required for the aqueous solution $(26 \mathrm{~h})$ and the denim wastewater $(1 \mathrm{~h})$.

According to the results shown in figure $6 \mathbf{d}$, $\mathrm{K}_{2} \mathrm{FeO}_{4}$ showed considerately improved color removal efficiency compared to $\mathrm{Na}_{2} \mathrm{FeO}_{4}$, due the difference in solubility. The potassium ion has an ionic radius of $1.33 \AA$, while that of the sodium ion is 1 $\AA$. As the cation size increases in a compound with the same anion, the solubility decreases. Thus, the concentration of $\mathrm{K}_{2} \mathrm{FeO}_{4}$ was lower but its chemical activity and reaction capacity were higher; $\mathrm{Na}_{2} \mathrm{FeO}_{4}$ had a higher concentration and solubility but lower chemical activity in the solution.

The removal efficiencies achieved are shown in table III. An increase in the BOD was observed, which in turn caused an increase in the biodegradability index (0.21 to 0.98$)$. This confirms that the biorefractory compounds were oxidized/removed, and that the treatment could prevent damage to the aquatic environment.

Finally, after treatment by $\mathrm{K}_{2} \mathrm{FeO}_{4}, \mathrm{UV}$-Vis spectra of the wastewater before and after 30 min of treatment were obtained in order to verify the removal of the dye from denim wastewater using the peak $661 \mathrm{~nm}$. The results shown in figure 8 confirmed that the maximum removal was achieved using $200 \mathrm{mg} / \mathrm{L}$ of $\mathrm{K}_{2} \mathrm{FeO}_{4}$. This coincided with the previously obtained results.

The sludge obtained after treatment with $\mathrm{K}_{2} \mathrm{FeO}_{4}$ was analyzed by infrared spectroscopy, and its spectrum was compared with that of the untreated denim wastewater. As shown in figure 9 and table $\mathbf{V}$, different bands associated with different functional groups were observed in the two spectra. Analysis of these bands indicated that some of the aromatic organic compounds present in the wastewater were oxidized to aliphatic compounds.

The signal of the N-H group disappears after the treatment, as well as some of the bands corresponding to aromatic groups, confirming the partial oxidation of the samples. The denim wastewater contained organochlorine compounds that were partially oxidized by the treatment; the corresponding signal

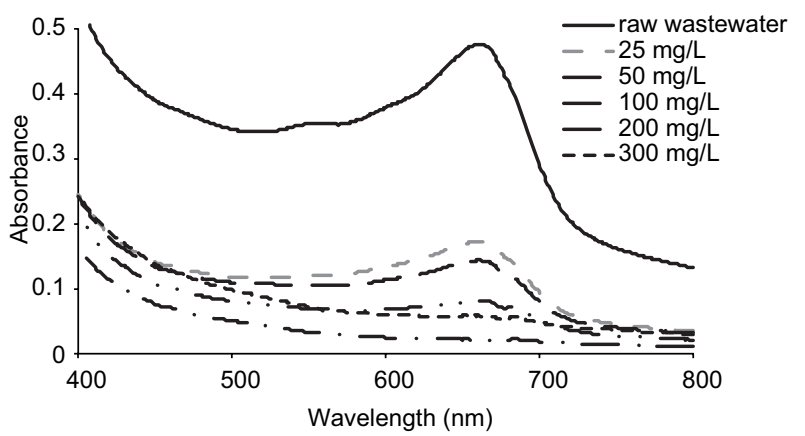

Fig 8. Ultraviolet visible spectra before and after treatment by $\mathrm{K}_{2} \mathrm{FeO}_{4}$ at different doses $(\mathrm{mg} / \mathrm{L})$

disappeared from the spectrum. The indigo dye in the wastewater was oxidized to various degradation byproducts (isatin, carboxylic acids, carbon dioxide, and ammonia). These results allow a possible mechanism to be determined, as shown in figure 10. The iron sludge (hydroxide and oxyhydroxides) formed during the treatment could remove aromatic compounds and promote the coagulation process.

According to the chemical species diagrams (Medusa program), $\mathrm{SO}_{4}{ }^{2-}$ and $\mathrm{PO}_{4}{ }^{3-}$ possibily formed several complexes, solid compounds and species in solution: $\mathrm{Ca}_{5}\left(\mathrm{PO}_{4}\right)_{3} \mathrm{OH}_{(\mathrm{s})}, \mathrm{MgFe}_{2} \mathrm{O}_{4(\mathrm{cr})}, \mathrm{KSO}_{4}^{-}$, and $\mathrm{MgPO}_{4}^{-}$.

\section{CONCLUSIONS}

Ferrate (VI) was found to be a good oxidant to remove dye from aqueous solution and a textile wastewater sample, and the treated water exhibited good physical and chemical qualities. The optimal operational conditions for the electrosynthesis of ferrate were determined to be room temperature $\left(25^{\circ} \mathrm{C}\right)$, a current density of $100 \mathrm{~mA} / \mathrm{cm}^{2}$ and $\mathrm{NaOH} 20 \mathrm{M}$, yielding $6.89 \mathrm{~g} / \mathrm{L}$ of ferrate. Sodium and potassium ferrate were synthesized at room temperature and showed high stability due to the positive effect of the BDD cathode on the production of ferrate.

The maximum dye removal percentages were achieved using sodium ferrate at a dose of $300 \mathrm{mg} / \mathrm{L}$ for all the dye concentrations evaluated $(10-100 \mathrm{mg} / \mathrm{L}$ of indigo blue dye), while efficiencies of 94 and $96 \%$ were obtained for dye concentrations of 20 and $30 \mathrm{mg} / \mathrm{L}$ dye concentration, respectively, using a dose of $200 \mathrm{mg} / \mathrm{L}$. On the other hand, potassium ferrate showed better color removal efficiency than sodium ferrate in denim wastewater. The optimum 


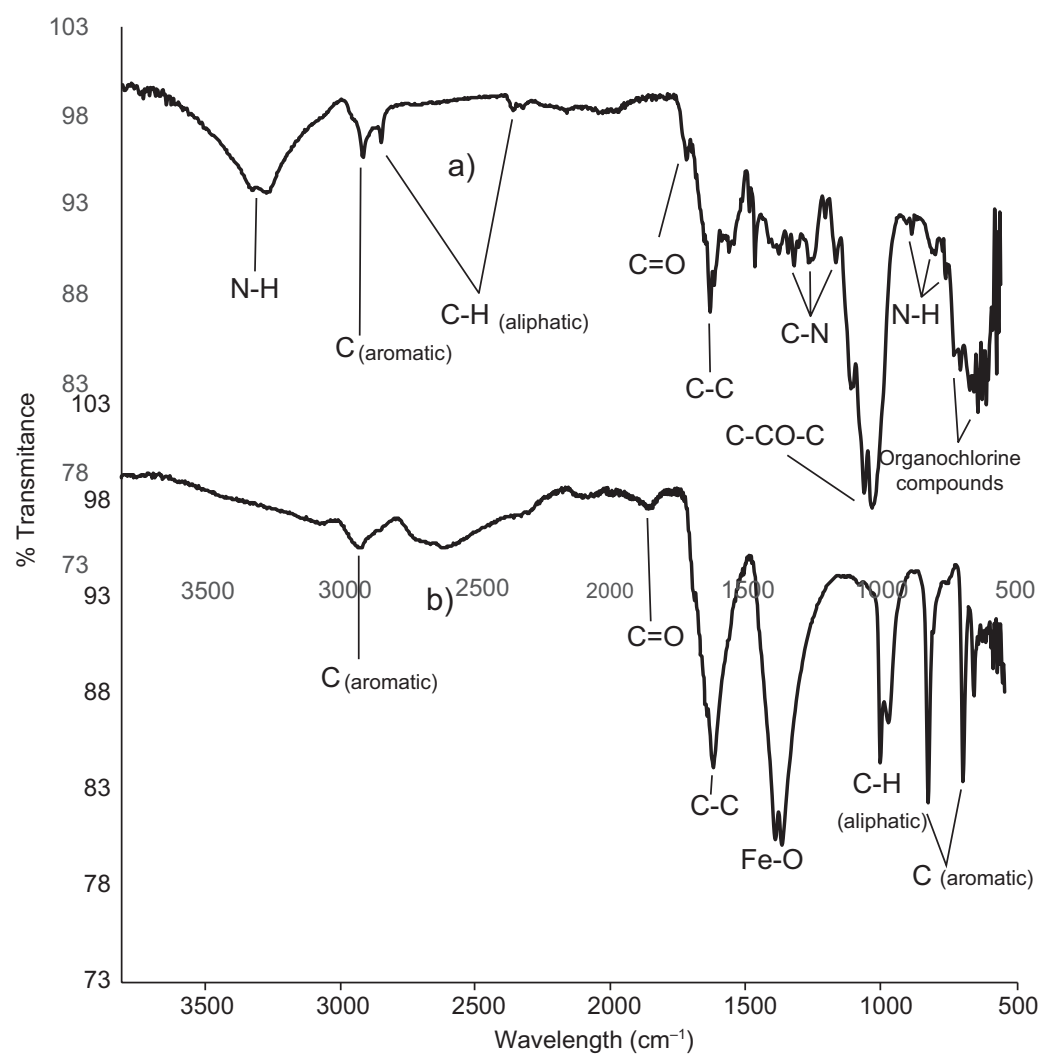

Fig 9. Infrared spectra. a) sludge, b) denim wastewater

TABLE V. ASSOCIATED FUNCTIONAL GROUP ACCORDING TO INFRARED SPECTRA

\begin{tabular}{|c|c|c|c|}
\hline \multicolumn{2}{|c|}{ Sludge } & \multicolumn{2}{|c|}{ Denim wastewater } \\
\hline Wavelength $\left(\mathrm{cm}^{-1}\right)$ & Functional group & Wavelength $\left(\mathrm{cm}^{-1}\right)$ & Functional group \\
\hline $3325-3278$ & $\mathrm{~N}-\mathrm{H}$ & 2916 & $\mathrm{C}$ aromatic \\
\hline $2920,1369,1311$ & $\mathrm{C}$ aromatic & 2584 & $\mathrm{C}-\mathrm{H}$ aliphatic \\
\hline $2846-2353$ & $\mathrm{C}-\mathrm{H}$ aliphatic & 1843 & $\mathrm{C}=\mathrm{O}$ \\
\hline 1712 & $\mathrm{C}=\mathrm{O}$ & 1616 & $\mathrm{C}-\mathrm{C}$ \\
\hline 1624 & $\mathrm{C}=\mathrm{C}$ & 1384 & $\mathrm{Fe}-\mathrm{O}$ \\
\hline $1319,1242,1157$ & $\mathrm{C}-\mathrm{N}$ & 1365 & $\mathrm{Fe}-\mathrm{O}$ \\
\hline 1099 & $\mathrm{C}-\mathrm{CO}-\mathrm{C}$ & 1002,972 & $\mathrm{C}-\mathrm{H}$ aliphatic \\
\hline $875,794,756$ & $\mathrm{~N}-\mathrm{H}, \mathrm{C}$ aromatic & 829,702 & $\mathrm{C}$ aromatic \\
\hline 694,644 & Organochlorine compounds & & \\
\hline
\end{tabular}

dose was $200 \mathrm{mg} / \mathrm{L} \mathrm{K}_{2} \mathrm{FeO}_{4}$ at $30 \mathrm{~min}$. When the same dose of $\mathrm{Na}_{2} \mathrm{FeO}_{4}$ was added, the color removal efficiency reached only $72.85 \%$. The treatment time for the textile wastewater was lower than that of the aqueous indigo blue solutions due to the presence of inorganic ions.
After the denim wastewater treatment, the biodegradability index of the wastewater showed a significant increase ( 0.21 to 0.98$)$, which confirmed that the biorefractory compounds were oxidized/ removed, and thus that the treatment could prevent damage to the aquatic environment. 

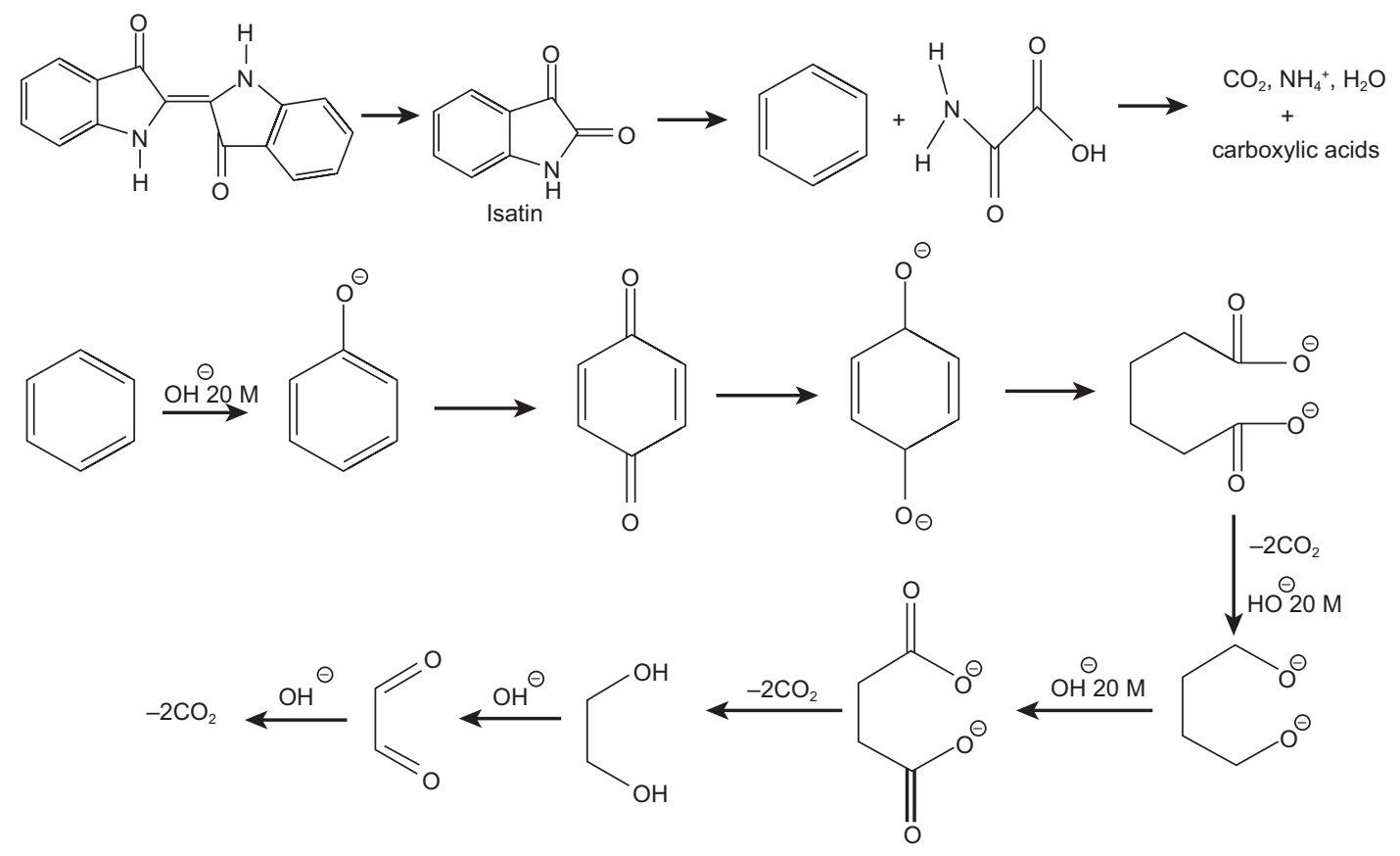

Fig 10. Indigo blue dye removal by $\mathrm{K}_{2} \mathrm{FeO}_{4}$

\section{ACKNOWLEDGMENTS}

The authors thank the Consejo Nacional de Ciencia y Tecnología of Mexico for the financial support granted through the research project 219743 and the scholarship (CVU 622426) for Castañeda-Juárez.

\section{REFERENCES}

Albuquerque L. F., Salgueiro A. A., Melo J. L. S. and Chiavone-Filho O. (2013). Coagulation of indigo blue present in dyeing wastewater using a residual bittern. Sep. Purif. Technol. 104, 246-249. https://doi. org/10.1016/j.seppur.2012.12.005

Ali H. (2010). Biodegradation of synthetic dyes: A review. Water Air Soil Poll. 213 (1), 251-273. https://doi. org/10.1007/s11270-010-0382-4

Almazán-Sánchez P. T., Solache-Ríos M. J., LinaresHernández I. and Martínez-Miranda V. (2016). Adsorption-regeneration by heterogeneous Fenton process using modified carbon and clay materials for removal of indigo blue. Environ. Technol. 37 (14), 1843-1856. https://doi.org/10.1080/09593330.2015.1133718

Alsheyab M., Jiang J.-Q. and Stanford C. (2009). On-line production of ferrate with an electrochemical method and its potential application for wastewater treatment: A review. J. Environ. Manage. 90 (3), 1350-1356. https://doi.org/10.1016/j.jenvman.2008.10.001
Alsheyab M., Jian, J.-Q. and Stanford C. (2010). Electrochemical generation of ferrate (VI): determination of optimum conditions. Desalination 254 (1-3), 175-178. https://doi.org/10.1016/j.desal.2009.11.035

APHA (2012). Standard methods for the examination of water and wastewater. 22nd ed. American Public Health Association. Washington, USA, $1360 \mathrm{pp}$

Barış̧̧ S., Ulu F., Särkkä H., Dimoglo A. and Sillanpää M. (2014). Electrosynthesis of Ferrate (VI) ion using high purity iron electrodes: optimization of influencing parameters on the process and investigating its stability. Int. J. Electrochem. Sc. 9, 3099-3117.

Beck F., Kaus R. and Oberst M. (1985). Transpassive dissolution of iron to ferrate(VI) in concentrated alkali hydroxide solutions. Electrochim. Acta. 30 (2), 173183. https://doi,org/10.1016/0013-4686(85)80079-7

Blanco J., Torrades F., Morón M., Brouta-Agnésa M. and García-Montaño J. (2014). Photo-Fenton and sequencing batch reactor coupled to photo-Fenton processes for textile wastewater reclamation: feasibility of reuse in dyeing processes. Chem. Eng. J. 240, 469-475. https:// doi.org/10.1016/j.cej.2013.10.101

Bouze, K. and Bergmann H. (1999). Comparison of pure and white cast iron dissolution kinetics in highly alkaline electrolyte. Corros. Sci. 41 (11), 2113-2128. https://doi.org/10.1016/S0010-938X(99)00036-0

Bouzek K., Schmidt M. J. and Wragg A. A. (1999). Influence of electrolyte composition on current yield during ferrate(VI) production by anodic iron dissolution. 
Electrochem. Commun. 1 (9), 370-374. https://doi. org/10.1016/S1388-2481(99)00075-2

Ciabatti I., Tognotti F. and Lombardi L. (2010). Treatment and reuse of dyeing effluents by potassium ferrate. Desalination 250 (1), 222-228. https://doi.org/10.1016/j. desal.2009.06.019

De Jager D., Sheldon M. S. and Edwards W. (2014). Colour removal from textile wastewater using a pilot-scale dual-stage MBR and subsequent RO system. Sep. Purif. Technol. 135, 135-144. https://doi.org/10.1016/j. seppur.2014.08.008

De Koninck M. and Bélanger D. (2003). The electrochemical generation of ferrate at pressed iron powder electrode: comparison with a foil electrode. Electrochim. Acta. 48 (10), 1435-1442. https://doi.org/10.1016/ S0013-4686(03)00021-5

Ding Z., Yang C. and Wu Q. (2004). The electrochemical generation of ferrate at porous magnetite electrode. Electrochim. Acta. 49 (19), 3155-3159. https://doi. org/10.1016/j.electacta.2004.01.031

Eng Y. Y., Sharma V. K. and Ray A. K. (2006). Ferrate(VI): Green chemistry oxidant for degradation of cationic surfactant. Chemosphere 63 (10), 1785-1790. https:// doi.org/10.1016/j.chemosphere.2005.08.062

Forgacs E., Cserháti T. and Oros G. (2004). Removal of synthetic dyes from wastewaters: a review. Environ. Int. 30 (7), 953-971. https://doi.org/10.1016/j.envint.2004.02.001

Han Q., Dong W., Wang H., Liu T., Sun F., Ying Y. and Yan X. (2013). Effects of coexisting anions on decolorization of azo dye X-3B by ferrate(VI) and a comparative study between ferrate(VI) and potassium permanganate. Sep. Purif. Technol. 108, 74-82. https:// doi.org/10.1016/j.seppur.2013.01.053

Han Q., Dong W., Wang H., Liu T., Tian Y. and Song X. (2018). Degradation of tetrabromobisphenol A by ferrate(VI) oxidation: performance, inorganic and organic products, pathway and toxicity control. Chemosphere 198, 92-102. https://doi.org/10.1016/j. chemosphere.2018.01.117

He W., Wang J., Shao H., Zhang J. and Cao C. (2005). Novel KOH electrolyte for one-step electrochemical synthesis of high purity solid $\mathrm{K}_{2} \mathrm{FeO}_{4}$ : Comparison with $\mathrm{NaOH}$. Electrochem. Commun. 7 (6), 607-611. https://doi.org/10.1016/j.elecom.2005.04.011

He W., Wang J., Yang C. and Zhang J. (2006). The rapid electrochemical preparation of dissolved ferrate(VI): effects of various operating parameters. Electrochim. Acta 51 (10), 1967-1973. https://doi.org/10.1016/j. electacta.2005.03.077

Jiang J.-Q. and Lloyd B. (2002). Progress in the development and use of ferrate(VI) salt as an oxidant and coagulant for water and wastewater treatment. Water
Res. 36 (6), 1397-1408. https://doi.org/10.1016/S00431354(01)00358-X

Jiang J.-Q., Wang S. and Panagoulopoulos A. (2006). The exploration of potassium ferrate(VI) as a disinfectant/ coagulant in water and wastewater treatment. Chemosphere 63 (2), 212-219. https://doi.org/10.1016/j. chemosphere.2005.08.020

Jiang J. Q. (2007). Research progress in the use of ferrate(VI) for the environmental remediation. J. Hazard. Mater. 146 (3), 617-623. https://doi.org/10.1016/j. jhazmat.2007.04.075

Karthikeyan S., Titus A., Gnanamani A., Mandal A. B. and Sekaran G. (2011). Treatment of textile wastewater by homogeneous and heterogeneous Fenton oxidation processes. Desalination 281, 438-445. https://doi. org/10.1016/j.desal.2011.08.019

Khandegar V. and Saroha A. K. (2013). Electrocoagulation for the treatment of textile industry effluent: a review. J. Environ. Manage. 128, 949-963. https://doi. org/10.1016/j.jenvman.2013.06.043

Lee Y., Yoon J. and Von Gunten U. (2005). Spectrophotometric determination of ferrate $(\mathrm{Fe}(\mathrm{VI}))$ in water by ABTS. Water Res. 39 (10), 1946-1953. https://doi. org $/ 10.1016 /$ j.watres.2005.03.005

Li C., Li X. Z. and Graham N. (2005). A study of the preparation and reactivity of potassium ferrate. Chemosphere 61 (4), 537-543. https://doi.org/10.1016/j. chemosphere.2005.02.027

Li G., Wang N., Liu B. and Zhang X. (2009). Decolorization of azo dye orange II by ferrate(VI), hypochlorite liquid mixture, potassium ferrate(VI) and potassium permanganate. Desalination 249 (3), 936-941. https:// doi.org/10.1016/j.desal.2009.06.065

Licht S., Naschitz V., Halperin L., Halperin N., Lin L., Chen J. and Liu B. (2001). Analysis of ferrate(VI) compounds and super-iron $\mathrm{Fe}(\mathrm{VI})$ battery cathodes: FTIR, ICP, titrimetric, XRD, UV/VIS, and electrochemical characterization. J. Power Sources. 101 (2), 167-176. https://doi.org/10.1016/S0378-7753(01)00786-8

Manenti D. R., Módenes A. N., Soares P. A., EspinozaQuiñones F. R., Boaventura R., Bergamasco R. and Vilar V. J. P. (2014). Assessment of a multistage system based on electrocoagulation, solar photo-Fenton and biological oxidation processes for real textile wastewater treatment. Chem. Eng. J. 252, 120-130. https:// doi.org/10.1016/j.cej.2014.04.096

Martínez-Huitle C. A. and Brillas E. (2009). Decontamination of wastewaters containing synthetic organic dyes by electrochemical methods: A general review. App. Catal. B-Environ. 87 (3-4), 105-145. https://doi. org/10.1016/j.apcatb.2008.09.017

Mácová Z., Bouzek K., Híveš J., Sharma V. K., Terryn R. J. and Baum J. C. (2009). Research progress in the 
electrochemical synthesis of ferrate(VI). Electrochim. Acta. 54 (10), 2673-2683. https://doi.org/10.1016/j. electacta.2008.11.034

Nawaz M. S. and Ahsan M. (2014). Comparison of physico-chemical, advanced oxidation and biological techniques for the textile wastewater treatment. Alexandria Engineering Journal 53 (3), 717-722. https:// doi.org/10.1016/j.aej.2014.06.007

Nikolić-Bujanović L., Čekerevac M., Vojinović-Miloradov M., Jokić A. and Simičić M. (2012). A comparative study of iron-containing anodes and their influence on electrochemical synthesis of ferrate(VI). J. Ind. Eng. Chem. 18 (6), 1931-1936. https://doi.org/10.1016/j. jiec.2012.05.007

Pearce C. I., Lloyd J. R. and Guthrie J. T. (2003). The removal of colour from textile wastewater using whole bacterial cells: a review. Dyes Pigments 58 (3), 179196. https://doi.org/10.1016/S0143-7208(03)00064-0

Punzi M., Mattiasson B. and Jonstrup M. (2012). Treatment of synthetic textile wastewater by homogeneous and heterogeneous photo-Fenton oxidation. J. Photoch. Photobio. A. 248, 30-35. https://doi.org/10.1016/j. jphotochem.2012.07.017

Raghu S., Lee C. W., Chellammal S., Palanichamy S. and Basha C. A. (2009). Evaluation of electrochemical oxidation techniques for degradation of dye effluents: a comparative approach. J. Hazard. Mater. 171 (1-3), 748-754. https://doi.org/10.1016/j. jhazmat.2009.06.063

Rai Prabhat K., Lee J., Kailasa S. K., Kwon E. E., Tsang Y. F., Ok Y. S. and Kim K.-H. (2018). A critical review of ferrate(VI) - based remediation of soil and groundwater. Environ. Res. 160, 420-448. https://doi. org/10.1016/j.envres.2017.10.016

Ramseier M. K., Peter A., Traber J. and Von Gunten U. (2011). Formation of assimilable organic carbon during oxidation of natural waters with ozone, chlorine dioxide, chlorine, permanganate, and ferrate. Water Res. 45 (5), 2002-2010. https://doi.org/10.1016/j. watres.2010.12.002

Schroyer J. M. and Ockerman L. T. (1951). Stability of ferrate(VI) ion in aqueous solution. Analytical Chemistry 23 (9), 1312-1314. https://doi.org/10.1021/ ac60057a028

Sharma V. K. (2011). Oxidation of inorganic contaminants by ferrates (VI, V, and IV)-kinetics and mechanisms: a review. J. Environ. Manage. 92 (4), 1051-1073. https:// doi.org/10.1016/j.jenvman.2010.11.026
Sharma V. K. (2013). Ferrate(VI) and ferrate(V) oxidation of organic compounds: kinetics and mechanism. Coordin. Chem. Rev. 257 (2), 495-510. https://doi. org/10.1016/j.ccr.2012.04.014

Sharma V. K., Mácová Z., Bouzek K. and Millero F. J. (2010). Solubility of ferrate(VI) in $\mathrm{NaOH}-\mathrm{KOH}$ mixtures at different temperatures. J. Chem. Eng. Data. 55 (12), 5594-5597. https://doi.org/10.1021/je100417d

Shin J., Lee D., Hwang T.-M. and Lee Y. (2018). Oxidation kinetics of algal-derived taste and odor compounds during water treatment with ferrate(VI). Chem. Eng. J. 334, 1065-1073. https://doi.org/10.1016/j. cej.2017.10.057

Sánchez-Carretero A., Rodrigo M. A., Cañizares P. and Sáez C. (2010). Electrochemical synthesis of ferrate in presence of ultrasound using boron doped diamond anodes. Electrochem. Commun. 12 (5), 644-646. https:// doi.org/10.1016/j.elecom.2010.02.020

Verma A. K., Dash R. R. and Bhunia P. (2012). A review on chemical coagulation/flocculation technologies for removal of colour from textile wastewaters. J. Environ. Manage. 93 (1), 154-168. https://doi.org/10.1016/j. jenvman.2011.09.012

Villanueva-Rodríguez M., Sánchez-Sánchez C. M., Montiel V., Brillas E., Peralta-Hernández J. M. and Hernández-Ramírez A. (2012). Characterization of ferrate ion electrogeneration in acidic media by voltammetry and scanning electrochemical microscopy. Assessment of its reactivity on 2,4-dichlorophenoxyacetic acid degradation. Electrochim. Acta 64, 196-204. https://doi. org/10.1016/j.electacta.2012.01.021

Wagner W. F., Gump J. R. and Hart E. N. (1952). Factors affecting stability of aqueous potassium ferrate(VI) solutions. Anal. Chem. 24 (9), 1497-1498. https://doi. org/10.1021/ac60069a037

Xu G. R., Zhang Y. P. and Li G. B. (2009). Degradation of azo dye active brilliant red X-3B by composite ferrate solution. J. Hazard. Mater. 161 (2-3), 1299-1305. https://doi.org/10.1016/j.jhazmat.2008.04.090

Zou J.-Y. and Chin D.-T. (1988). Anodic behaviour of carbon steel in concentrated $\mathrm{NaOH}$ solutions. Electrochim. Acta 33 (4), 477-485. https://doi. org/10.1016/0013-4686(88)80164-6 